Julian Warzecha SAC

\title{
Trochę bliżej... Ponowna odpowiedź Łukaszowi Niesiołowskiemu Spanò
}

Jestem wdzięczny za odpowiedź i podane wyjaśnienia. One na pewno służą sprawie i nas zbliżają. Rzeczywiście, najbardziej odpowiedni termin na określenie tego, o czym dyskutujemy, to „Palestyna”. Ja tego zasadniczo nie podważałem. Ma on jednak, jak rzetelnie autor informuje, także swoje słabości i ograniczenia. Dlatego jego wyłączne stosowanie nie byłoby też właściwe.

Trudno mi się jednak zgodzić z twierdzeniem mojego polemisty, że używam nazwy „Izrael” w opozycji do Filistynów (s. 59). Powiedziałbym raczej, że odróżniam dzieje Hebrajczyków od tych, którzy stanowili część „Ludów Morza”. Do nich przecież trudno zaliczyć tych pierwszych, choć zdarzały się między nimi związki, także małżeńskie (np. casus Samsona).

Trochę jednak szkoda, że sympatyczny i tak zatroskany o poziom historii dawnej Palestyny w naszym kraju autor potraktował moje uwagi wybiórczo.

Pomijam moje zastrzeżenia co do stylu, w jakim sformułował rozpoznanie stanu, w którym jego zdaniem znajduje się omawiana dziedzina nauki. Brak mi w tym tekście odpowiedzi na zarzut pewnej jednostronności w wyborze literatury, którą określiłbym jako awangardową. Czy wolno nam to robić? Może i wolno - młodość ma do tego prawo, ale takie podejście może nie wytrzymać próby czasu.

Druga sprawa. Nie rozumiem, dlaczego mój polemista nie podjął pytania, czy - jeśli stan historii Palestyny w Polsce jest tak alarmujący - za tę sytuację nie są przede wszystkim odpowiedzialni fachowi historycy starożytności. To jest i powinno być przede wszystkim ich zadanie. Może to jest tak, że jeśli bibliści nieudolnie próbują coś robić w tej dziedzinie, to dzieje się tak dlatego, że nie znajdują u innych zainteresowania tą tematyką? Przytoczę fragment z mojej pierwszej odpowiedzi, jaką dałem autorowi: „Nic nie stoi przecież na przeszkodzie, by właśnie historycy, będąc lepiej przygotowani do obchodzenia się ze źródłami i znaleziskami archeologicznymi, uprawiali historię Kanaanu czy Palestyny, w jej etnicznej różnorodności i całości. Nie widać jednak, by historycy zajmujący się starożytnością, zwłaszcza dziejami 
Bliskiego Wschodu, jakoś się nadmiernie do tego spieszyli. Bibliści nie roszczą sobie wyłączności do zajmowania się dziejami biblijnego Izraela i Kanaanu". Jeśli przy tym używam liczby mnogiej, to dlatego, że spośród biblistów nie tylko ja próbowałem coś robić w tej dziedzinie.

Szkoda też, że autor nie ocenił, jak nowe tendencje, na których uwzględnieniu tak bardzo mu zależy, znalazły swoje odbicie w mojej Historii dawnego Izraela (Warszawa 2005). Mam odczucie, że niczego istotnego nie pominąłem, choć to nie oznacza, że ze wszystkimi awangardowymi tezami muszę się zgadzać.

Nie znajduję u Ł. Niesiołowskiego żadnego słowa na temat moich wyjaśnień, że nie można traktować a priori tekstów biblijnych jako z zasady nieprzydatnych do rekonstrukcji dziejów dawnego Izraela. To jest właśnie jedna z cech niektórych, bo przecież nie wszystkich, awangardowych historyków zajmujących się dziejami dawnej Palestyny. Jest przy tym charakterystyczne, że tak podejrzliwie nie patrzą oni na inne dawne dokumenty.

Nie spotkałem ani słowa wyjaśnienia na temat pisowni wyrazu „Bóg” (u autora „bóg”). Pytam więc ponownie: Czy także na tym miałaby polegać awangarda?

A może brak odpowiedzi na te kwestie mam rozumieć jako przyznanie mi racji? Qui tacet, consentire videtur.

Kończę jeszcze jednym przytoczeniem z poprzedniej mojej wypowiedzi: „Zachęcam do wypełnienia luk, które pozostały w historiografii Palestyny. Pracy nikomu nie braknie! Bibliści przyjmą z ogromną wdzięcznością np. nowoczesne opracowanie dziejów Filistynów i innych ludów zamieszkujących Kanaan przed Izraelitami i koegzystujących później obok nich czy wspólnie z nimi”. A może uda nam się także zrobić coś wspólnie? Żyjemy przecież w czasie prac zespołowych i interdyscyplinarnych. 